\title{
世界のオープンアクセス政策と日本： 研究と学術コミュニケーションへの影響
}

研究成果として論文を出版し、新しい知見や学識を世に残し、人類の知識として 共有するという学問の有り様は、21世紀に入って急速にその姿を変えつつある。研 究資金の使い方の中に、論文をオープンアクセス出版することを求め、また、その 成果として論文情報が産学官で自在に活用することができ、社会に還元しようとす る国策が、例えばHorizon 2020に代表されるように欧米で活発に議論されている。 研究が学際化し、人と情報がグローバルなスケールで自在に動く今、日本にも欧米 の政策の影響が現れ始めている。論文出版を、研究費を使ってオープンアクセス出 版（無料で閲覧出来るように）することにとどまらず、誰でも論文著作権を履行で きるようにする利活用の仕組み(クリエイティブコモンズ)も、日本に漂着している。 我が国では、2010年に発出した日本学術会議の提言を受け、我が国発の国際的な リーディングジャーナル育成プロジェクトが強力に推進されている。上記のこのよ うな学問を取り巻く新たな環境が、研究現場やコミュニケーションの場面、そして ジャーナル育成プロジェクトに及ぼす影響と対策を多面的に科学者が議論する場と して日本学術会議主催学術フォーラムを企画した。

2014年3月13日に企画した学術フォーラムは、日本学術会議講堂がほぼいつぱ いになる盛況さで、活発な質疑も行われ、本件に関する学術コミュニティーの関心 の高さを伺うことになつた。

本特集では、学術フォーラムの登壇者に国内外の現状を紹介していただき、また、 それに基づいて議論された内容を、広く、科学者コミユニティーと共有することを 通じて、科学者一人一人が考える際の基礎となることを目指している。多くの方々 に読んでいただき、情報を共有するとともに、皆様が、日本から世界への学術情報 発信のあり方を考え、それぞれの分野ごとに、効果的な国際情報発信をしていただ くことを、心からお願ししたい。

第22期日本学術会議科学者委員会学術誌問題検討分科会副委員長 同広報分科会副委員長 （独）海洋研究開発機構東日本海洋生態系変動解析プロジェクトチームプロジェクト長 北里 洋 